J. Clin. Chem. Clin. Biochem.

Vol. 16, 1978, pp. 601-605

\title{
Factors Affecting the Radioimmunological Determination of Carcinoembryonic Antigen in Human Plasma
}

By C. Wagener and $H$. Breuer

Institut für Klinische Biochemie, Universität Bonn

(Received February 22/June 20, 1978)

Summary: Two commercially available test kits for the determination of carcinoembryonic antigen (CEA) in human plasma were compared with each other under various experimental conditions.

These studies were carried out

(a) with an indirect method (Hoffmann-La Roche), in which the plasma sample is extracted by perchloric acid, and .

(b) with a direct method (CEA-IRE-SORIN) without prior treatment of the plasma.

Using plasma from patients with cancer, the CEA values, obtained by the direct method, were about 5 times higher on the average than those determined by the indirect procedure. This result is primarily due to the quantitative differences between the different standard preparations. Perchloric acid which served to extract CEA from the plasma had significantly less influence. The standard buffer of the CEA-IRE-SORIN-assay did not affect the level of plasma CEA; in contrast, when the standard buffer of the Hoffmann-La Roche assay was used, the CEA values were lower when compared with a buffer with a protein composition similar to that of the sample to be investigated. These results strongly indicate that a standardised method with an internationally accepted CEA standard is required for the quantitative determination of CEA.

Einflußgrößen bei der radioimmunologischen Bestimmung des carcinoembryonalen Antigens im Plosma des Menschen

Zusammenfassung: Zwei kommerzielle Testkits zur Bestimmung des carcinoembryonalen Antigens (CEA) im Plasma des Menschen wurden unter verschiedenen Gesichtspunkten miteinander verglichen. Dabei handelte es sich einmal um eine indirekte Bestimmungsmethode (Hoffmann-La Roche), bei der die zu untersuchende Plasmprobe mit Perchlorsäure extrahiert wurde, zum anderen um ein direktes Verfahren (CEA-IRE-SORIN) ohne Vorbehandlung des Plasmas.

Die mit der direkten Methode ermittelten CEA-Werte bei Carcinompatienten lagen im Durchschnitt etwa fünfmal höher als bei Verwendung des indirekten Verfahrens. Dieser Befund ist hauptsächlich auf die quantitativen Unterschiede zwischen den verschiedenen Standardpräparationen zurückzuführen. Einen deutlich geringeren Einfluß hatte die Verwendung von Perchlorsäure, die zur Extraktion von CEA diente. Während der Standardpuffer im CEA-IRESORIN-Assay ohne Wirkung auf die Höhe der gemessenen CEA-Konzentrationen war, lagen die CEA-Werte bei Verwendung des Standardpuffers des Hoffmann-La Roche-Assay niedriger im Vergleich mit einem Puffer, dessen Proteinzusammensetzung mit derjenigen der zu unterșuchenden Probe identisch war.

Diese Ergebnisse unterstützen die Forderung nach standardisierten Methoden zur Bestimmung von CEA unter Verwendung eines international akzeptierten CEA-Standards.

\section{Introduction}

It has been reported that CEA plasma levels and the upper limit of the normal range as measured by radioimmunoassay depend on several factors. Thus, different standard preparations may lead to different results $(1,2)$.
Furthermore, the absorption of the antisera seems to have an influence on the radioimmunological CEA determination (3). Moreover, several authors reported higher CEA concentrations when the extraction of plasma or serum with perchloric acid was omitted $(4,5,6)$. Fi:nally, the choice of the standard buffer and its protein 
content play an important role in the CEA radioimmunoassays $(3,4,7)$.

In the present study, two commercially available radioimmunoassays for the determination of CEA were compared; the two assays differ with respect to

(a) the standard preparation,

(b) absorption of antisera,

(c) extraction of the plasma with perchloric acid and

(d) the buffer used for the standard determination.

Each of these factors may affect the radioimmunological determination of CEA. Accordingly, the influence of various standard preparations and buffers as well as of the extraction with perchloric acid were studied in detail.

\section{Materials and Methods}

The reagents for the radioimmunoassay of CEA in plasma were obtained from Hoffmann-La Roche, Basel, Switzerland, and from CEA-IRE-SORIN (CIS), distributed by Isotopendienst West, F. R. Germany. Blood was collected in EDTA vacutainers (Becton \& Dickinson, Heidelberg, F. R. Germany). If not stated otherwise, the assays were performed according to the instructions of the manufacturers. In the indirect Hoffmann-La Roche assay, the plasma sample is extracted with $0.6 \mathrm{~mol} / 1$ perchloric acid before CEA is assayed. In the direct CIS assay the plasma sample is analysed.without prior extraction.

The CIS assay was also performed with perchloric acid-extracted plasma samples (indirect determination). For this purpose plasma was extracted in $0.6 \mathrm{~mol} / 1$ perchloric acid, dialysed four times against deionised water and finally against $0.02 \mathrm{~mol} / 1$ barbital buffer, $\mathrm{pH}$ 8.3. $0.1 \mathrm{ml}$ of the nondialy sable residue was used for the assay. For the standard curve, normal plasma, supplied by the manufacturer, was extracted in $0.6 \mathrm{~mol} / 1$ perchloric acid and dialysed as described; $0.1 \mathrm{ml}$ was used. In order to obtain conditions which were comparable to those of the original direct assay, $50 \mu \mathrm{l}$ of non-extracted plasma with no detectable CEA was taken from a pool of normal non-smokers, and was pipetted into all tubes.

Binding of proteins to CEA was investigated by stirring the plasma in $3 \mathrm{~mol} / 1 \mathrm{NaCl}$ solution for $2 \mathrm{~h}$ at room temperature before extraction with perchloric acid $(8,9)$. The perchloric acid extract was processed as mentioned above. In a patient with very high CEA concentrations in plasma, the binding curve was compared with the binding of the standards of both the CIS and the Hoffmann-La Roche assay, using the Hoffmann-La Roche antiserum (for details, see 1. c. (10)).

t-test and regression analysis were performed as usual. As nonparametrical test, the Wilcoxon matched pairs signed rank test was applied. Standards were measured in triplicate and samples in duplicate.

\section{Results}

The fraction of false positive results was determined in a plasma panel, containing 55 plasma samples from 37 patients with various nonmalignant diseases (liver cirrhosis, hepatitis, ulcerative colitis, Crohn's disease, gastric and duodenal ulcer, emphysema, bronchitis, pneumonia, tuberculosis) and from 18 heavy smokers.

In 46 of the 55 subjects, CEA concentrations were normal in both the Hoffmann-La Roche assay and the CIS assay; in two subjects, CEA was elevated in both assays.
Three subjects had normal CEA values in the CIS assay, but exhibited elevated concentrations in the HoffmannLa Roche assay. On the other hand, four subjects showed elevated values in the CIS assay, but normal values in the Hoffmann-La Roche assay.

In 42 patients with gastrointestinal malignancies and eight patients with bronchial carcinomas, preoperative plasma concentrations were determined by both methods (fig. 1). The fraction of false negative results was lower in the direct CIS assay (0.42) than in the indirect Hoffmann-La Roche assay (0.52). The median of the 50 patients in the direct method was $13.6 \mu \mathrm{g} / 1$ and in the in direct method $2.4 \mu \mathrm{g} / 1$. Calculation of the regression of the values within the limits of detection $(y=9.1 X-10.8)$ yielded a coefficient of correlation of $\mathrm{r}=0.91$ (excluding one outlier).

In 26 patients, the CIS assay was performed by its original (direct) and by a modified (indirect) procedure (fig. 2). The values, obtained by the direct procedure were significantly higher than those detected by the indirect method $(p<0.01)$. The median for the direct CIS assay was $16.7 \mu \mathrm{g} / 1$ and that for the indirect assay $12.7 \mu \mathrm{g} / 1$. The values within the limits of detection gave a regression of $y=0.86 x+12.44, r=0.83$.

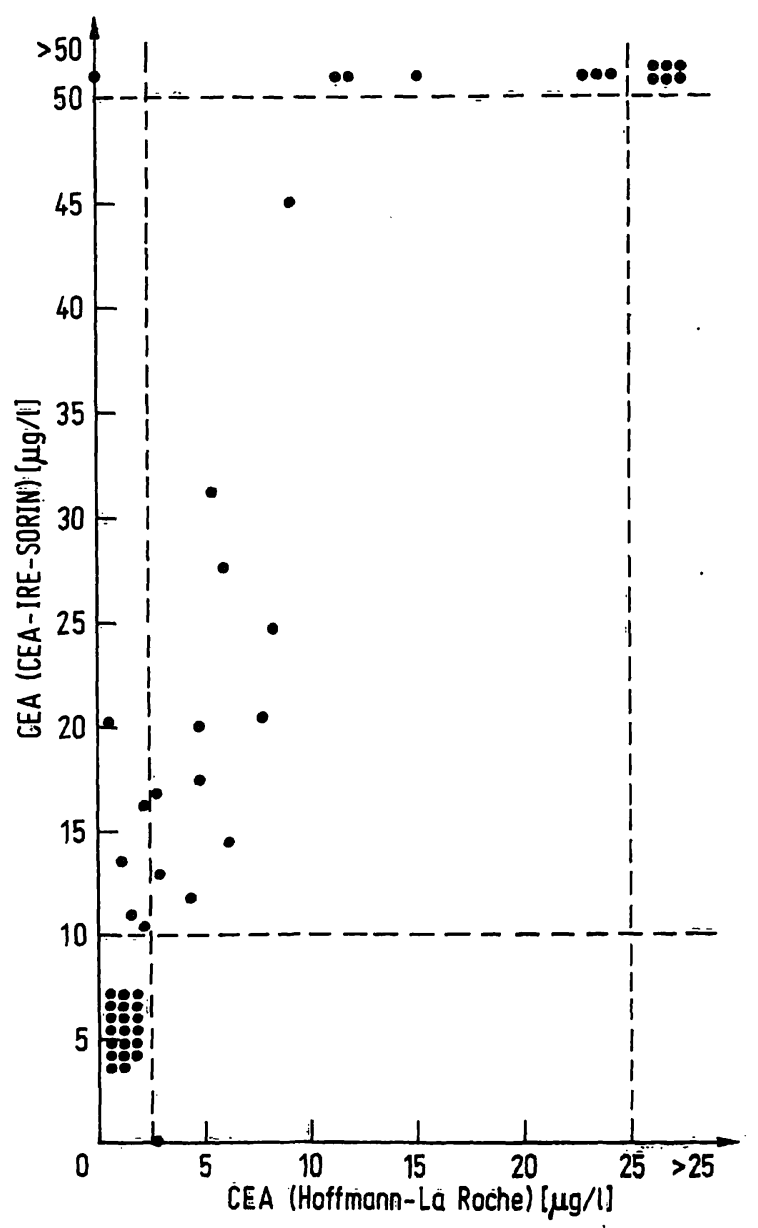

Fig. 1. Preoperative plasma concentrations of CEA in patients with gastrointëstinal and bronchial carcinomas, measured with the direct CEA-IRE-SORIN and the indirect Hoffmann-La Roche assay. 


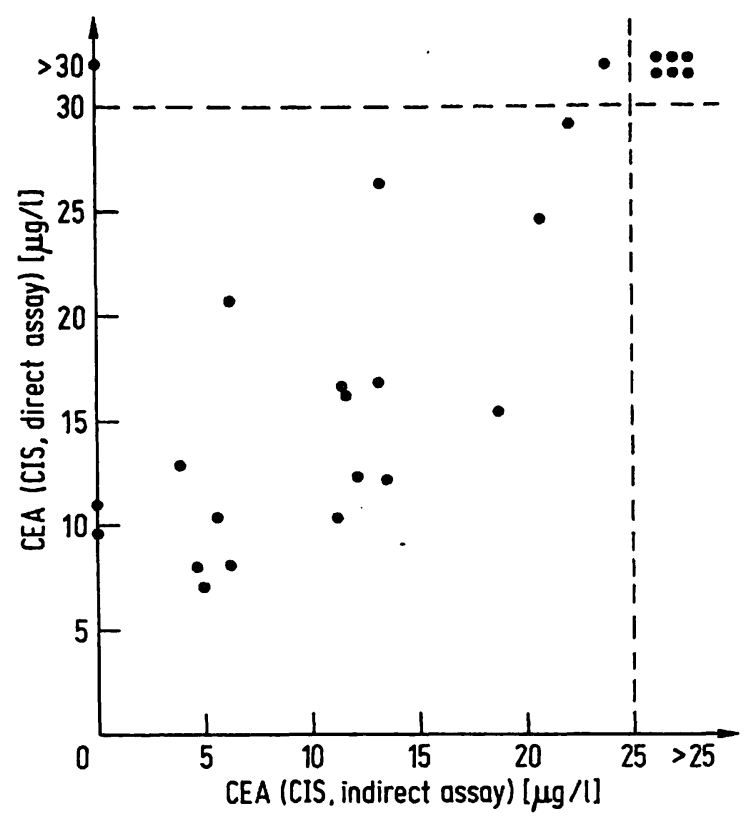

Fig. 2. Direct and indirect determination of plasma-CEA by the CIS assay in patients with malignant and nonmalignant diseases.

In figure 3 , the concentrations of CEA as measured by the original (indirect) Hoffmann-La Roche assay and by the modified (indirect) CIS assay were compared. In the indirect CIS assay, the CEA values were clearly higher (median $11.6 \mu \mathrm{g} / \mathrm{l}$ ) than in the indirect Hoffmann- $\mathrm{La}$ Roche assay $(2.3 \mu \mathrm{g} / \mathrm{l})$. The concentrations gave a regression of $y=4.4 x-0.06, r=0.86$.

In one patient, CEA concentrations, as measured by the direct CIS assay and the indirect Hoffmann-La Roche assay, were highly discordant. One preoperative and three postoperative determinations yielded values of less than $2.5 \mu \mathrm{g} / \mathrm{l}$ in the Hoffmann-La Roche assay,

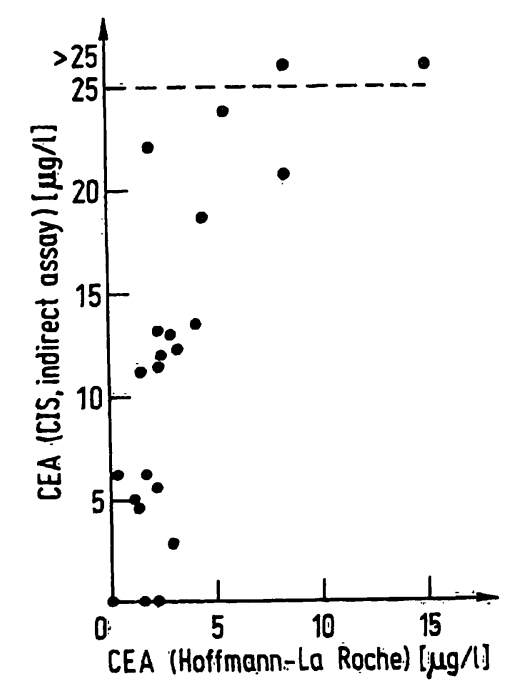

Fig. 3. Indirect determination of plasma CEA by the HoffmannLa Roche and the CIS assays in patients with malignant and nonmalignant dieseases. whereas in the CIS assay the CEA concentrations varied between 62 and $304 \mu \mathrm{g} / 1$. Treatment of the plasma with $3 \mathrm{~mol} / 1 \mathrm{NaCl}$ prior to extraction with perchloric acid did not result in higher values. In the CIS assay, a significant decrease in the concentration from 103 to less than $5 \mu \mathrm{g} / \mathrm{l}$ was observed, when the plasma sample was treated with perchloric acid prior to the determination.

Double dilutions of a plasma sample with a high CEA content were analysed by the Hoffmann-La Roche assay; in addition, the same samples were measured using the CIS standard instead of the Roche standard. The results are summarised in table 1 . As can be seen, higher plasma values are estimated with the CIS standard. Furthermore, with increasing dilution of the plasma sample, the CEA values show a tendency to rise, when the CIS standard is used for calculation.

According to the instructions of the manufacturer, the standard in the CIS assay system is analysed in the same buffer as the plasma samples. To obtain a comparable protein content, normal plasma from a plasma pool is added instead of the sample to be investigated. The CEA content of the normal plasma which is supplied by the manufacturer (CEA-IRE-SORIN) was found to be less than $0.8 \mu \mathrm{g} / 1$ in the Hoffmann-La Roche assay.

In the Hoffmann-La Roche assay, the standard is measured in a buffer that is different from the buffer against which the perchloric acid-extracted plasma samples are dialysed. The influence of different buffers and their protein content on the standard curve is shown in figure 4 . The use of a protein-free $0.01 \mathrm{~mol} / 1$ ammonium acetate buffer, $\mathrm{pH} 6.8$, leads to an over-estimation of CEA; in contrast, the use of EDTA buffer, as supplied by Hoffmann-La Roche for the standard curve, leads to an under-estimation of CEA in the higher concentration range, when compared with a standard curve performed in the dialysed perchloric acid extracts from a normal human plasma pool.

Using the same plasma pool, the interassay variance was lower in the direct CIS assay; the coefficient of variation of the same plasma sample was $5.7 \%$ in the direct CIS assay $(\bar{x}=40.4 \mu \mathrm{g} / 1)$, which yields higher results, and $11.1 \%$ in the indirect Hoffmann-La Roche $(\bar{x}=8.1 \mu \mathrm{g} / \mathrm{l})$ which yields lower results.

Table 1. Determination of CEA in different dilutions of the same plasma using the Hoffmann-La Roche and the CIS standards. Antiserum: Hoffmann-La Roche.

\begin{tabular}{|c|c|c|}
\hline $\begin{array}{l}\text { Dilution } \\
\text { of plasma sample }\end{array}$ & $\begin{array}{l}\text { CEA-Roche } \\
\mu \mathrm{g} / 1\end{array}$ & CEA-CIS \\
\hline $\begin{array}{l}1: 8 \\
1: 16 \\
1: 32 \\
1: 64\end{array}$ & $\begin{array}{r}942 \\
1,084 \\
969 \\
1,017\end{array}$ & $\begin{array}{l}2,014 \\
2,541 \\
2,794 \\
2,800\end{array}$ \\
\hline
\end{tabular}




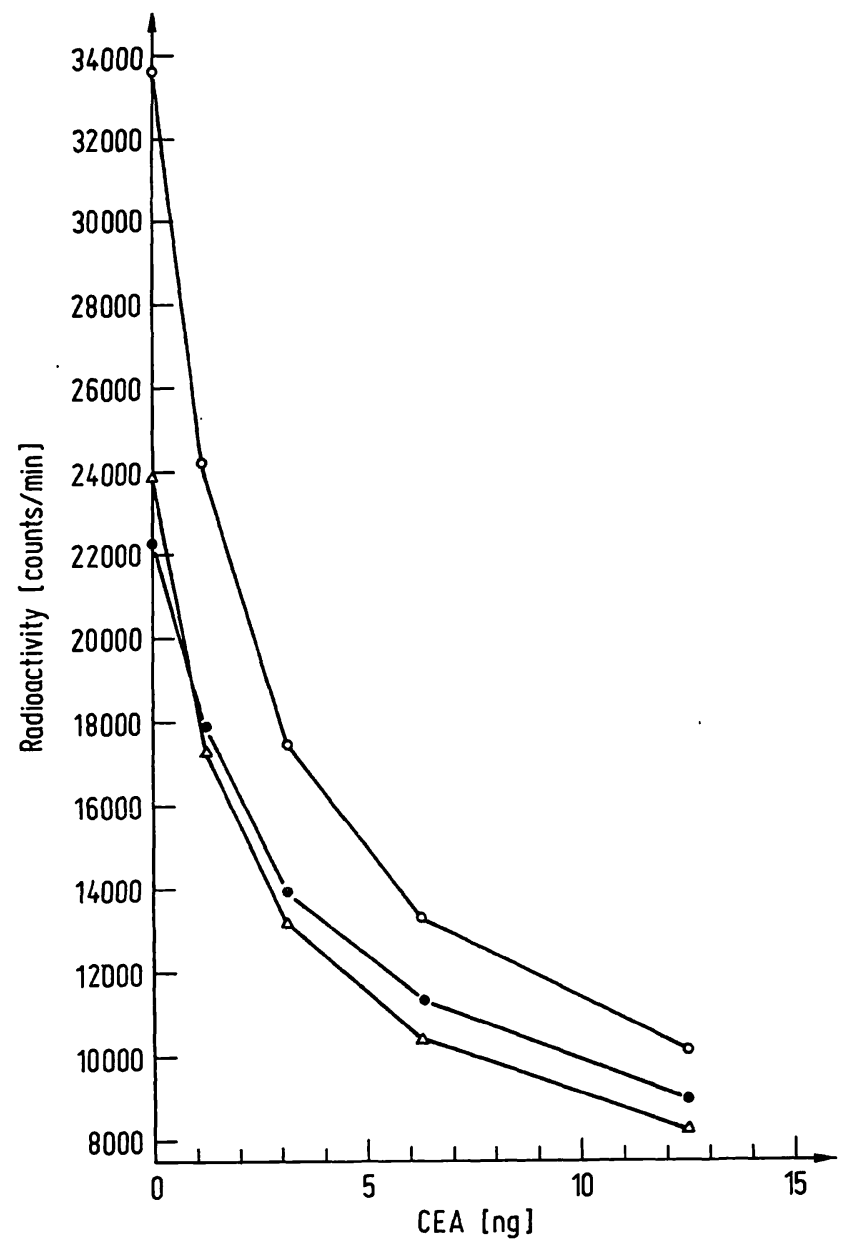

Fig. 4. CEA standard curves using different buffers in the Hoffmann-La Roche assay.

○-0 $0.01 \mathrm{~mol} / \mathrm{l}$ ammonium acetate buffer

$\longrightarrow 0.01 \mathrm{~mol} / \mathrm{l}$ ammonium acetate buffer containing perchloric acid-ex tracted normal plasma

$\backsim \Delta$ Buffer received from Hoffmann-La Roche

\section{Discussion}

In the present paper, it has been demonstrated that the results of CEA determinations in human plasma are strongly influenced by a number of factors, including the standard preparations, the perchloric acid extraction and the different buffers, which were studied in more detail.

\section{Influence of standard preparations}

In has been previously described that more CEA-CIS than CEA-Roche is needed to reach a comparable inhibition in the radioimmunoassay of CEA (10). As shown in the table and in figure 3, this leads to higher value for plasma CEA, when the CIS standard is used. These findings are in agreement with the results reported by Ashman et al. (1) and Vrba et al. (11). In contrast, Persijn \& Korsten (12) found that the standard curves obtained with Hoffmann-La Roche standard and antiserum on the one hand and Hoffmann-La Roche antiserum and standard according to Krupey et al. (13) on the other hand, were completely superimposable. If one accepts that different standard preparations result in different CEA serum concentrations, then one would expect that the upper limit of the normal range of CEA depends on the standard preparation used. Surprisingly, this seems not to be the case, since in many investigations the upper limit was between 2.5 and $3 \mu \mathrm{g} / 1$ irrespective of the standard preparation used. This finding applies to the direct assay $(12,14,15)$ as well as to the indirect assay $(14,16,17)$. The contradictory results mentioned above may be explained by the varying water content (18), the salt concentration (12) or different isolation procedures $(18,19)$ of the standard preparations. There were also qualitative differences demonstrable between the CIS standard on the one hand and plasma CEA on the other hand (table 1). This finding is in agreement with the results reported previously (10), where heterogenous behaviour of tumour CEA was demonstrable in the CIS assay.

It follows that a standardised procedure for the isolation of CEA appears to be a prerequisite for a reliable determination of CEA in plasma.

\section{Influence of extraction with perchloric acid}

The influence of extraction with perchloric acid on the CEA concentrations was observed after perchloric acid strated in figure 2. After extraction of plasma with perchloric acid, the levels of CEA were significantly lower, compared with the results obtained using the direct assay. In some patients, a highly significant decrease in CEA concentrations was observed after perchloric acid extraction. In one patient, pre- and postoperative CEA concentrations lay between 100 and $300 \mu \mathrm{g} / 1$ in the direct assay, but were undetectable in the indirect Hoffmann-La Roche and CIS assays. Perchloric acid insolubility in this case could not be traced to the binding of CEA by perchloric acid-insoluble proteins, since treatment with high molar sodium chloride solution prior to extraction with perchloric acid did not result in higher CEA values.

Though perchloric acid-insoluble species of CEA were found in a certain percentage of patients, the quantitative differences between the indirect Hoffmann-La Roche and the direct CIS assay are primarily due to quantitative differences between the standard preparations (fig. 3).

The results in the literature concerning the effect of perchloric acid extraction on the CEA plasma concentrations are also contradictory. Some authors reported higher values for CEA in the direct assay $(4,5,6)$ and a higher percentage of false positive results (20). Others found no significant differences with respect to the upper limits of the normal range when extraction with perchloric acid was omitted $(12,14,15,21)$. Comparing the direct and the indirect methods, factors such as the source and the absorption of antisera as well as the standard isolation procedures may play an important role. 


\section{Influence of buffers}

To attain similar protein concentrations in the sample and standard tubes, plasma from normal subjects is added to the standards in the CIS assay. As has been pointed out by Kupchik et al. (7) and Sorokin et al. (17), CEA-containing plasma from normal subjects which is added to the standard tubes can cause an under-estimation of CEA in the samples. In fact, when normal plasma used in the CIS assay was measured for CEA content by the indirect Hoffmann-La Roche assay, no detectable CEA was found. Thus, it can be concluded that the use of normal plasma has no significant influence on the CEA levels in the CIS assay.

In the Hoffmann-La Roche assay, the standard buffer is different from the buffer in which the samples are analysed. This causes an under-estimation of CEA in the concentration range above $2 \mu \mathrm{g} / 1$ (fig. 4 ). The differences between the CEA values, as measured by the two assays may in part be due to this effect. As was pointed out by various authors, the protein content of the standard buffer significantly influences the result of CEA determination $(3,4,7,12)$.

\section{Antisera}

The influence of the source and of the absorption of the antisera on the results of the radioimmunoassay of CEA is not yet clear. It was not further investigated, because commercial kits were used.

\section{Acknowledgement}

The authors wish to express their gratitude to Professor Dr. $H$. Rohr, Siegburg, and to Dr. Ruth Schmitz, Bergisch-Gladbach, for supplying plasma samples from their patients. The valuable technical assistance of Miss Sigrid Nissen is gratefully acknowledged.

\section{References}

1. Ashman, L. K., Ludbrook, J. \& Marshall, V. R. (1975), Br. Med. J. 2, 721-724.

2. Edgington, T. S., Plow, E. F., Chavkin, C. I., Deheer, D. T. \& Nakamura, R. M. (1976), Bull. Cancer 63, 673-688.

3. Das, S., Das, B. R. \& Terry, W. D. (1976), Cancer Res. 36, 1954-1961.

4. Laurence, D. J. R., Stevens, U., Bettelheim, R., Darcy, D., Leese, C., Turberville, C., Alexander, P., Johns, E. W. \& Neville, A. M. (1972), Br. Med. J. 3, 605-609.

5. MacSween, J. M., Warner, N. L., Bankhurst, A. D. \& Mackay, I. R. (1972), Br. J. Cancer 26, 356-360.

6. Franchimont, P., Debruche, M. L., Zangerlee, P. F. \& Proyard, J. (1973), Ann. Immunol. 124, 619-630.

7. Kupchik, H. Z., Żamcheck, N. \& Saravis, C. A. (1973), J. Nat. Cancer Inst. 51, 1741-1749.

8. Heidelberger, M. \& Kendall, F. E. (1936), J. Exp. Med. 63, 819-826.

9. Heidelberger, M. \& Kabat, E. A. (1938), J. Expl Med. 67, 181-199.

10. Wagener, C. \& Breuer, H. (1978), this J. 16, 323-327.

11. Vrba, R., Alpert, E. \& Isselbacher, K. J. (1975), Proc. Nat. Acad. Sci. USA 72, 4602-4606.
12. Persijn, J.-P. \& Korsten, C. B. (1976), this J. 14, 377-387.

13. Krupey, J., Wilson, T., Freedman, S. O. \& Gold, P. (1972), Immunochemistry 9, 617-622.

14. Searle, F., Lovesey, A. C., Roberts, B. A., Rogers, G. T. \& Bagshawe, K. D. (1973), J. Immunol. Methods 4, 113-125.

15. Go, V. L. W., Schutt, A. J., Moertel, C. G., Summerskill, W. H. J. \& Butt, H. R. (1972), Gastroenterology 62, 754.

16. Thomson, D. M. P., Krupey, J., Freedman, S. O. \& Gold, P. (1969), Proc. Nat. Acad. Sci. USA 64, 161-167.

17. Sorokin, J. J., Kupchik, H. Z., Zamcheck, N. \& Dhar, P. (1972), Immunol. Commun. 1, 11-24.

18. Newman, E. S., Petras, S. E., Georgiadis, A. \& Hansen, H. D. (1974), Cancer Res. 34, 2125-2130.

19. Plow, E. F. \& Edgington, T. S. (1975), Int. J. Cancer 15, 748-761.

20. Khoo, S. K., Hunt, P. S. \& Mackay, I. R. (1973), Gut 14, 545-548.

21. Ashman, L. K., Ludbrook, J. \& Marshall, V. R. (1977), Clin. Chim. Acta 74, 77-84.
Prof. Dr. Heinz Breuer Inst. f. Klin. Biochem. Venusberg

D-5300 Bonn 
. $\cdot$ 